\title{
一 環境教育としての食文化教育の立場から—
}

\author{
杉本 史生 \\ 近畿大学非常勤講師

\section{Studying the Significance of the External Effect of Agriculture: Food Culture Education through the Lens of Environmental Education}

\author{
Fumio SUGIMOTO \\ Kinki University \\ （受理日2011年9月 1日）
}

\section{Iはじめに}

\section{1. 研究目的}

環境教育は環境問題を未然に防止及び解決する 人間 (UNESCO-UNEP 1976)、持続可能な社会 を構築する人間（国立教育政策研究所 2007）の 育成を目的とする営為である1)。食料自給率の低 迷や食品公害、大量の食品廃裹物など、「食」を めぐる問題は環境並びに持続可能な社会の視点か ら対策が必要とされ、環境教育はその対策として 果たすべき役割がある。環境教育研究分野におい て、1990年代以降、「食」をめぐる問題に関する 議論がさかんになっており、その解決に貢献する 研究の進展が求められている2)。そうした既存研 究のひとつに、鬼頭秀一（1996）の社会的リンク 論を参照した山下宏文 (2004)がある。山下 (2004) はこれまで部分的に食文化教育が実践され、ある いは「食育」という形で多くの実践が行なわれつ つあると述べる。しかし、断片的・部分的な実践 では、「食」に抒ける「かかわりの全体性の回復」 （鬼頭 1996）や新たな食文化の創造に向かってい くことは到底不可能であろう。いまや、環境教育 に抢いても「食」の問題を食文化の問題として しっかりと位置づけるべきときであり、我々の食 生活をもう一度「生身」の関係（鬼頭 1996）に 再構築するため、環境教育が重要な役割を果たさ
なければならない、というのが山下の主張であ る。そして、環境教育としての食文化教育の内容 的構成要件を以下のように論じ、今後その教育の 系統化・体系化に向け、内容的構成要件と方法的 要件から考察する必要性を指摘している3)。

「食育」の視点 ——エネルギー」や「消費者 教育」の要素を強調することで、「望ましい食習 慣の形成」を「環境と調和した生活」や「賢い消 費者」や「持続可能な社会」と結びつけることが 必要である。

「生業」の視点——生活」としての「食」と「生 業」としての農業、林業、水産業等の第一次産業 を密接に結びつけること、そして、「生活」と「生 業」の相互関係が「文化」であり、「環境」でも あることに着目することが必要である。

「歴史・伝統」の視点——地域の中で個性的 · 歴史的に豊かな履歴として形成された食文化を見 直し、継承し、再構築していくこと、日本の食文 化を歴史的にとらえ、その形成、定着、変質といっ たことを環境史的にみていくこと、さらには食文 化を文明論的にみていくことなどが必要である。

「食料保障」の視点 一一食」を世界的な視野 からとらえ、食料自給率の低さを如何に高めてい くかという見方が必要である。（山下 2004 149）

\section{問い合わせ先 $\mp 631-8505$ 奈良市中町 3327-204 近畿大学農学部 E-mail: sugimotofu@yahoo.co.jp}


環境問題の本質は、人間と「生身」の関係にあっ た自然が「切り身」化していくことである（鬼頭 1996）。現代の食生活は鬼頭が指摘するように、 まさに「切り身」化している。「食」に関する「社 会的・経済的リンクと文化的・宗教的リンクによ るネットワーク」が切断され（鬼頭 1996）、人々 は自然を人間と切り離して認識しがちな社会状況 に置かれているように思われる4)。先述の要件は その生活を再び「生身」の関係へと回復する、す なわち「かかわりの全体性」を回復するうえで妥 当な見解である5)。

そこで、次に環境教育としての食文化教育の系 統化・体系化が重要な課題となる。では、どうす れば系統化・体系化できるであろうか。その方途 として、まずこれらの要件を満たすうえで鍵とな る教育内容を明確化し、環境教育としての食文化 教育の立場から意義づける作業が久かせない。特 に筆者は、その鍵となる教育内容として、農業の 外部効果がふさわしいのではないかと考える。本 稿ではこのような関心のもと、環境教育としての 食文化教育の立場から、農業の外部効果を学ぶ意 義を考察することを目的とする。なお、環境教育 としての食文化教育とは「環境教育の目的の実現 を明確に意図し、食文化に関する教育内容や方法 で実施する教育」を意味する言葉であると定めて おく。

「食」をめぐる環境教育に関しては食文化教育 以外に、最近では鈴木善次（2007）並びに小野瀬 剛志（2010）のように、食環境教育という名称の もとで、その体系化を図るという提案もみられ る。このうち、鈴木 (2007) は用語「食環境教育」 を定義したうえで、「持続可能な社会」の構築に 向けた「食環境教育」論を展開している。「食環 境教育」の定義は、「食環境を軸に人間環境やそ こにみられる環境問題への関心、理解を深め、よ り望ましいライフスタイル、大きくは文明のあり 方を考え、それを実現する能力・態度・実行力を 身につける活動」である。そして、この規定にあ る「食環境」は、「食」の「消費」段階にとどま らず、「『生産』段階から『消費』段階までの全体 を視野に入れ、その間に『人間環境』として直接・
間接に『関わり』をもつ事象の総体」を指す。「食 環境教育」は環境の視点を重視しており、その点 が関連用語である「食教育」「食農教育」、食育」 と異なると説明されている。

前出の山下 (2004) は「環境教育は本来、『か かわりの総体』としての環境を扱い、かかわりの あり方 (関係性) を問いなおし、かかわりを再構 築することにその本質があるのだから、かかわり 方の様式としての『文化』の問題はその中核とな らねばならないはずである」と述べ、環境教育が 「食」を扱う場合、「食文化」に着目した食文化 教育のあり方が追求されるべきことを提起してい る（山下 2004 149）。「食」をめぐる環境教育の 体系化を図る枠組みが複数存在する中で、当稿は 山下の問題提起を共有しながら、環境教育として の食文化教育の枠組みからの体系化に焦点をあ て、議論を深めていくことにしたい。

\section{2. 先行研究}

農業の外部効果を学ぶ意義を論じた先行研究 は、限られている。例えば、環境教育分野におい て教育に值する内容としては、以下のように、農 業の外部効果に相当する事象が提案されてきた。 すなわち、水田の貯水 - 水質浄化 - 地下水涵養並 びに地域の気象や生態系保持機能（鈴木 1993 ; 2002)、土砂崩壊防止と日本の原風景維持機能 (阿 部・佐島 2004)、ビニールハウス栽培と地球温暖 化との結びつき（鈴木 1993）、農業による表土の 流出や有害物質の環境への蓄積（北村 2000）、農 薬や遺伝子組換え作物の人体と生態系への影響 （鈴木 2002）などが、それである。しかし、これ らの先行研究は総じて部分的な説明に終始してお り、農業の外部効果という経済学の概念で事象を 総合的に捉え、それを学ぶ意義がどこにあるのか について、環境教育としての食文化教育の立場か ら論じているわけではない。農業の外部効果を学 ぶ意義を、環境教育としての食文化教育の立場か ら考察するアプローチとして、前述の経済学の概 念を用いる。その結果、先行研究で明示されてい ない新たな知見が導出されると考える。 


\section{3. 研究方法}

研究方法は文献調查で、農業の外部効果という 経済学の概念を用いてその効果に相当する事象を 総合的に捉えつつ、それを学ぶ意義を考察する方 法である。次の第 II 章において、外部効果の存在 は、環境問題発生の一要因であるとする経済学的 な考え方を確認する。第章では農業の外部効果 の種類と性質について、簡潔に述べる。第 $\mathrm{IV}$ 章で は教育内容としての同効果が、山下（2004）が提 示した食文化教育の内容的構成要件を満たすにあ たり、どう関連しているかを検討する。以上の結 果に基づき、第 $\mathrm{V}$ 章において本研究目的に対する 考察をまとめ、今後の課題を示す。

\section{II「市場の失敗」と外部効果の存在}

持続可能な発展を脅かす環境問題は、経済学に おいて「市場の失敗」(market failure) や「政府 の失敗」(government failure) として捉えられる (浅野 2008)。「市場の失敗」は市場が有効に機能 せず、パレート最適（Pareto optimum）な資源 配分を達成できていない状態を意味する。パレー 卜最適な資源配分は無駄を完全に除去した効率的 な資源配分で、「あるひとりの消費者の効用（満 足度）を増加させるように資源を再配分しょうと すれば、必ず他の消費者の一部の満足度を低下さ せなくてはいけないような資源配分状態」（常木 2002）と厳密に定義される。環境経済学で著名 な細田衛士によると、市場は特定の条件、すなわ ち(1)完全競争条件、(2)凸性の条件 6)、(3)市場の普 遍性の条件を満たすとき、パレート最適を達成で きる。しかし、いずれかの条件をひとつでも満た すことができなければ、達成できなくなる。これ は狭義の「市場の失敗」と位置づけられている。 例えば、市場の普遍性の条件（人間の欲望に影響 を及ぼす物的・非物的な財には全て価格が成立す るという条件) を満たさない外部効果 (external effect)が存在する場合である(細田 2007 13-17)。

外部効果は外部性（externality）とも呼ばれ、 技術的外部効果と金銭的外部効果に区分される。 「市場の失敗」が生じるのは前者であり、この問 題を提起したのはピグウである（ピグウ 1954）。
通常、外部効果とは技術的外部効果を指すため (緒方 2006)、以下では技術的外部効果のことを 外部効果と表現する。

公共経済学を専門とする緒方隆（2006）は外部 効果を「市場を経由せずに、ある経済主体が別の 経済主体に影響を与えること」と規定しており、 本稿における定義はこれに沿う。ここでの経済主 体は生産者や消費者、及びそれら主体の人数の面 で少数と多数の場合がある。外部効果には、「別 の経済主体」に便益を与える影響である正の外部 効果（外部経済external economy）と、反対に 損害を与える影響である負の外部効果 (外部不経 済external diseconomy）とがある。

外部効果が存在するとき、「市場の失敗」を補 正するために一般に政府の介入が必要になる（植 田 1996 28)。資源の配分を市場の機能に委ねて おくことは、パレート最適達成の観点からすれ ば、不適切なのである。環境問題解決に向けた政 府による介入として、直接的規制、環境税、補助 金、損害賠償責任ルールの設定などの政策手段が 考えられる。しかし、政府の介入が環境保全とい う所期の目的を果たせず、経済の効率性を回復し 得ていないことがあり、これを「政府の失敗」と 呼ぶ（植田 1996 30）。

ここまで述べてきたような狭義の「市場の失 敗」に対し、広義の「市場の失敗」も存在する。 それは、経済学における価值判断基準と関連して いる。経済学では効率と並ぶ重要な価值判断基準 として、公平という概念がある。この基準による ならば、たとえ特定の条件を全て満たすことでパ レート最適を達成できたとしても、市場では十分 に解決できない分配の問題がある。これは広義の 「市場の失敗」として理解されている（細田 2007 15-24)。分配の問題について、細田 (2007) は市場経済がもたらす事後的結果の分配の不公平 のほか、事前的な初期分配の不公平、市場におけ る情報格差や参入差別など過程や手続きにおける 不公平の問題もある。さらに、個人間の公平の問 題だけでなく、所得階層などのグループ間の公平 や、国家間及び世代間の公平が問題になる、と説 明している。環境保全や持続可能な社会の構築に 
おいては、効率的な資源配分のほかに、ここで例 示した公平な分配のような社会的公正も考慮しな ければならない7)。

環境問題が発生する背景には、以上のような市 場経済のしくみが存在する。外部効果の存在は狭 義の「市場の失敗」が生じ、環境問題を発生させ る重要な要因であることは通説である。

\section{III 農業の外部効果の種類と性質}

農業には正と負の外部効果が存在する。これは 農業の外部効果と呼ばれるもので、農業を営む経 済主体が市場を経由せず、別の経済主体、つまり 生産者や消費者に与える正と負の影響のことであ る。

祖田修（2000）は、一般に正の外部効果として 認められている農業の影響として、以下の機能を 挙げている。すなわち、(1)水資源涵養、(2)土壤の 保全、(3)洪水防止、(4)地上・地下の貯水、(5)水や 大気の浄化、(6)臭気及び騒音防止、(7)自然と景観 の保全、8保健休養機能、(9)教育的機能が、それ である。一方、負の外部効果については、(1)化学 肥料や農薬多投による土壤污染・水質污染・野生 動植物の死滅、(2)水田からのメタンガスの発生、 (3)石油エネルギー利用による大気污染、(4)食品の 農薬污染による健康被害、さらに(5)発展途上国に おける森林の農地化と過放牧による自然破壊、並 びに地球温暖化への影響、海外で顕著な(6)地下水 多用による塩害、7)略奪的大規模農業による土壤 流出と地力低下、などが示されている。

浅野耕太（1998）は農林業が持つ機能に関し、 内部経済効果を発揮する機能、及び外部経済効果 を発揮する機能（公益的機能）に大別している ${ }^{8)}$ 。 後者は、「食料安全保障」「環境保全（国土・環境 保全、居住環境保全、生物資源保存)」「緑資源 · オープンスペース提供（景観保全、想い・安らぎ 提供)」「保健・休養（レクリエーション空間提 供)」「教育 (自然・情操教育環境提供)」「農山村 伝統文化維持」機能の6つに分けられる。「食料 安全保障機能」とは、「農産物の国内自給をつう じて国民に食料安全保障のオプション」を提供す る機能である。「国土・環境保全機能」としては $\lceil 大$ 気浄化、水源 - 水資源涵養、洪水防止、保水 遊水、水質浄化、土壤浸食防止、土砂崩れ防止、 物質分解、污染物浄化」「「居住環境保全機能」と して「防風、防塵、防砂、温度 - 湿度調節、騒音 の緩和、住景観維持」「生物資源保存機能」とし て「生物種の保護、生態系の維持」が挙げられて いる。「農山村伝統文化維持機能」は「ふるさと や地域固有の農山村文化、農山村慣習 - 伝統、風 土、農山村的社会活動、祭り、農山村景観を農業 を生活の基盤とする農山村をつうじて維持してい く機能」を意味する。つまり、外部経済効果とは 正の外部効果を指し、農業資源の適切な利用が あってはじめて発揮されるものである。農業の外 部効果の性質に関し、同書では「農薬の大量投入 によって地域住民の健康を害したり、安全でない 農産物で消費者の健康を損ったり、農業排水で地 域の地下水や河川を污染したりした場合、潜在的 に農林業がプラスの効果を発揮し得る可能性があ るにしても、実際にはマイナスの効果、外部不経 済効果を発揮している」と言及されている。

農業の外部経済について、『食料・農業・農村 基本法』（1999年 7 月 16 日制定）では農業の公益 的機能ではなく、「多面的機能」という用語を使 用している ${ }^{9)}$ 。その理由は文化の伝承機能、情操 涵養機能など、農業の外部経済は「公益性」とい う概念に該当しないような機能を包含するからで ある（食料・農業・農村基本政策研究会 2000）。 第 3 条では農業の「多面的機能」の具体例として、 「国土の保全、水源のかん養、自然環境の保全、 良好な景観の形成、文化の伝承」機能が明示され ている。この第 3 条は本法律において基本理念の ひとつに位置づけられており、「多面的機能」に ついては「国民生活及び国民経済の安定に果たす 役割にかんがみ、将来にわたって、適切かつ十分 に発揮されなければならない」と定めている。日 本では本法律に基づき、農業の外部経済の発揮に 関する対策が実施されている。

欧米諸国の農業は大規模畑作・有畜農業で特徵 づけられる。他方、わが国はアジア・モンスーン 地帯のもとで中小規模の水田農業を基礎とし、水 田農業はすぐれた国土保全機能を持つ（嘉田 
1999）。国土保全機能をはじめ、農業の外部経済 に関しては近年貨幣換算評価が盛んに行なわれて いる10)。また、佐藤和夫（2000）のように北海道 という地域を選定し、そこでの農業がもたらす外 部効果について、正と負の両面から貨幣換算評価 を実施した研究成果もある11)。農業には外部効果 が存在するものの、政府が政策介入を行なうこと で、経済の効率性を改善することができる。こう した農業の経済的評価は、その介入を適切に実施 する一判断材料を提示する点で有効である。

倉阪秀史（2004）は近年、政府が統治する主体 で、民間は統治される主体であるという図式が大 きく崩れてきているという。環境政策をはじめ、 政策の形成及び実施は一般的に行政に委ねるとい う考え方から、民間主体（企業、NGO、個人など） も具体的な政策形成に参画し、政策を自ら立案 · 実施するという考え方に変化してきている。そし て、民間主体の政策形成への参画については、従 来、国民は代議士を選出することを通じて間接的 ・全般的に参画してきたが、近年はそればかりで なく個別の問題に関して具体的に参画するルート が様々に用意されるようになった、と説明する ${ }^{12)} 。$ 農業・食料政策には、農業の外部効果がもたらす 「市場の失敗」を補正する政策が含まれる。倉阪 が説明する政策に関する一般的な考え方によると、 農業・食料政策の形成及び実施においては、政府 のほかに民間主体の役割の重要性が増している。

最近、日本の政策において、これまで $\mathrm{EU}$ 諸国 で農業の外部経済として強調されてきた生物多様 性の保全機能が高く評価されている。1990年代 末に制定された『食料・農業・農村基本法』第 3 条では、「多面的機能」の例として当機能は明文 化されていない。しかし、2007年7月に農林水産 省が策定した『農林水産省生物多様性戦略』、同 年 11 月に閣議決定された『第 3 次生物多様性国家 戦略』の中で、農業が持つ生物多様性の保全機能 は工業と対比しつつ、肯定的に意味づけられてい る。例えば、後者の文書では「わが国においては、 昔から人間による農林水産業の営みが、人々に とって身近な自然環境を形成し、多様な生物が生 息生育するうえで重要な役割を果たしてきまし
た」と記述されている。中島紀一（2010）は 1961年制定の『農業基本法』を転機とし、国を 挙げて推進してきた農業近代化政策において、農 業発展の基本線は自然改変 · 人工優位の方向に置 かれてきたと述べている。その結果、農村の生態 系は利便性と短期的な生産性の論理のもとに単純 化され (生態系の多様性の喪失)、農村生物の絶 滅などそこで生きていた生物の多様性が失われ (種の多様性の喪失)、単作化と作付品種の単純化 が進む（作物の遺伝的多様性の衰失）など、かつ て農業・農村が育んできた生物多様性の体制は崩 れてきた。しかし、『第3次生物多様性国家戦略』 においては自然共生型農業が目指されているこ と、並びに生物多様性の保全に資する国の農業・ 農村技術政策への転換が宣言されていることを明 らかにしている。

ここで、農業の外部効果の種類と性質につい て、2点指摘しておきたい。第1に、どのように 農業資源を利用するかによって、発揮される効果 の種類、及び程度が異なる。農業資源には農地、 農業用水、種子や肥料・農薬、農業技術などがあ る。農業は営農における地理的・気候条件、農作 物や農法が多様で、それぞれの資源利用の方法が ある。そして、佐藤が言及しているように、農業 は外部不経済という負の側面を有するが、外部不 経済を抑えながら外部経済を発揮させることが技 術的に可能であり（佐藤 2000）、そうした農業資 源の利用対策が望まれる。

第 2 に、生物多様性の保全機能のように個々の 効果に対する社会的評価は変化しうる。この点に 関して、日本の戦後史において上述した様々な外 部経済の存在が国内農業に対し、社会的な意義や 役割を与えてきた。そして、国内農業の外部経済 に対するそうした意味づけは近年多面的になって いる13)。確かに、市場原理は活発な経済活動に とって不可欠の基本的原則である。しかし、それ に基づく競争激化・貿易拡大は食料輸入国の農業 経営を淘汰し、農業の外部経済の発揮を損なう危 険性がある ${ }^{14)}$ 。現在、日本の農業はGDPに占め る割合が $0.9 \%$ （2007年度）で、農業就業人口の 減少と高齢化、耕地面積の減少並びに耕作放棄地 
の増加が生じ、衰退傾向にある（農林水産省 2010a 155-156；2010b 130-131，168)。農業の外 部経済の適切かつ十分な発揮に関する対策が講じ られ、人々の環境やアメニティ意識が高まりをみ せるなか、今後国内農業の正と負の外部効果に対 する社会的評価が注目される。

\section{$\mathrm{N}$ 食文化教育の要件と農業の外部効果}

教育内容としての農業の外部効果は、本稿冒頭 で引用した要件、つまり「食育」「生業」、「歴史・ 伝統」、「食料保障」の4つの要件を満たすにあた り、どのように関連しているであろうか。各要件 について、順に述べていくことにする。

第 1 に「食育」の視点からの要件である。これ は山下（2004）において、次の問題意識から示さ れたものである。

「食」のもっとも基本的な性質は、人間の生命 の維持や成長、そして健康の維持といったことで ある。「食育」が第一に目指しているのはまさに この点であり、「望ましい食習慣の形成」を通し て「健康と体力」を育むことである。食文化教育 においても、この点の重要性は変わりない。しか し、「食」を通した「かかわりの全体性」に迫る ためには、いくつかの視点を強調したり、付け加 えたりする必要がある。（山下 2004 146）

山下は強調並びに追加すべき「いくつかの視 点」として、「エネルギー」と「消費者教育」の 視点を挙げている。しかし、「エネルギー」につ いては、農業の外部効果に対して大きな意味を認 め難い。農業生産におけるエネルギー消費とそれ による大気污染は、「食」の生産から輸送・調理・ 再利用もしくは処分段階までの包括的なエネル ギー消費のうち、ごく一部にすぎないからである。

一方、「消費者教育」の内容的要素はどうか。 消費者教育と環境教育は前者が消費者問題、後者 が環境問題の発生とともにその必要性が生じたと いう、いわば問題解決志向の教育という点で共通 している（松葉口 2000）。また、消費の動向は環 境問題の発生源である点で、消費者教育は環境教
育と連接する ${ }^{15)}$ 。消費者教育の対象領域につい て、消費者教育支援センター（2006）は「安全」、 「契約・取引」、情報」、環境」に分類し、領域「環 境」の教育目標として次の 3 点を設定している。

目標(1) 商品の購入段階において、商品の環境 に関する情報を確認し、環境への影響に配慮した 商品を選択できる。

目標(2) 商品の使用・廃棄段階において、物を 大切にするとともに、消費生活が環境に及ぼす影 響を認識し、適切な対処ができる。

目標(3) 持続可能な社会を目指し、消費生活に 関わる環境保全の取り組みに協力して取り組むこ とができる。（消費者教育支援センター 2006 31）

農業の外部効果には、教育目標(1)と(3)の学習内 容的要素がある。この外部効果は食品の「環境に 関する情報」、並びに「消費生活に関わる環境」 事象である。加えて、農業の外部効果は、その便 益、あるいは損害が市場価格に反映されにくく、 環境問題発生の要因であり、消費者が学ぶに值す る事象であることによる。したがって、食文化教 育の内容に農業の外部効果を組込むことは、「消 費者教育」の要素が強調されることになる。また、 「食育」が最も目指している「望ましい食習慣の 形成」を通して「健康や体力」を育むことに対し、 「環境と調和した生活」の実現や「賢い消費者」 の育成、及び「持続可能な社会」の構築に結びつ けることができる。だが、特定の食品がどのよう な農業資源の利用方法で生産されたものか、商品 購入段階において消費者が確認できる食品の「外 部情報」16)に限界があることは否めない。

第 2 に生業」の視点からの要件である。農業 の外部効果は、「生活」と「生業」(鬼頭 1996) の相互関係に関する事象である。農業という「生 業」に伴って、「自然から人間に向かうべクトル が強い営み」（鬼頭 1996）が作用し、この作用は 人間による次の「生業」の働きかけに影響を及ぼ す。これは自然と人間の「かかわり方の様式」(山 下 2004）といえる。そして、農業の外部効果は 自然と人間の「かかわりの総体」（山下 2004）の 
うち、主に「社会的・経済的リンク」(鬼頭 1996) を表す。ゆえに、食文化教育の内容に農業の外部 効果を組込むことは、学習者に「生活」と「生業」 の相互関係が「文化」であり、「環境」でもある ことに着目させることができる。ただし、「生活」 としての「食」と、「生業」としての第一次産業 を密接に結びつけるという点では、農業の外部効 果の場合、林業や水産業の「生業」に関する事象 が欠如している。

第 3 に歴史・伝統」の視点からの要件である。 農業の外部効果は、この要件に深く関連する食品 の加工・調理法や食作法に関する事象が希薄であ る。だが、歴史の面でこれまでに認められている 正と負の外部効果の史実、伝統の面で「農山村伝 統文化維持機能」を含む。したがって、農業の外 部効果は地域の食文化を見直し継承・再構築する こと、日本の食文化を環境史的にみること、並び に食文化を文明論的にみることにおいて、補完的 な内容といえる。

第 4 に食料保障」の視点からの要件である。 農業の外部効果には「食」を世界的な視野から捉 え、日本の食料自給率を如何に高めていくかとい う見方を育成する要素が含まれる。例えば、外部 不経済の例として、日本向け輸出食料の生産によ り生じている海外での環境破壊がある。外部経済 の例は「食料安全保障機能」である。しかし、教 育内容としての農業の外部効果は、この要件を満 たすうえで不十分である。諸外国と日本の食料自 給率、世界の食料需給に関する現状と将来予測な ど、先述の例以外に関する内容が欠如しているか らである。

以上、教育内容としての農業の外部効果は、い ずれの要件をも十分に満たすわけではない。だ が、各要件を充足させる要素を持つため、環境教 育としての食文化教育の内容にこの外部効果を組 込むことは必要である。

\section{$\mathrm{V}$ まとめと今後の課題}

環境教育としての食文化教育の立場から、農業 の外部効果を学ぶ意義は次の点にあると結論づけ る。それは「食」における「かかわりの全体性」
の「社会的・経済的リンク」を回復し、持続可能 な社会を構築する人間の育成に寄与することであ る。

現代の社会において人々の食生活は「切り身」 化している。農業を通じた食料生産に携わらない 消費者は、農業という「生業」と「生活」の相互関 係について十分に認識し難いだろう。農業の外部 効果はこの相互関係に関する事象である。また、 市場を経由せずに与える影響、すなわち農業を営 む経済主体が別の経済主体に与える便益、並びに 損害が市場価格に反映されにくい影響により、狭 義の「市場の失敗」が生じ、環境問題を発生させ る要因ともなる。農業を営むある経済主体の農業 資源の利用が、いかなる経済主体にどのような外 部経済や外部不経済を与えているのか。この社会 事象について、子どもから高齢者までの消費者が 一般教育、あるいは専門教育の内容として学び、 認識を深化・発展させる。そうした認識は「食」 における「かかわりの全体性」回復のうち、特に 「社会的・経済的リンク」の回復に資するであろう。

そして、この回復は学習者の農業・食料政策に 対する関心と態度が向上し、持続可能な社会を構 留する人間の育成に寄与すると考える。農業の外 部効果は環境保全や持続可能な社会の構築と密接 に関係し、この効果の存在に伴う「市場の失敗」 を補正するためには、一般に政府の介入が必要と なるからである。学習者は持続可能な社会の構築 の視点から、農業・食料政策の現状とあり方に対 する関心を高めるであろう。また、農業資源の具 体的な利用方法を考慮しつつ、農業・食料政策の 過程に積極的に関与する態度を育むことが期待で きる。人々の食生活が「切り身」化する現代社会 にあって、日本では農業が衰退傾向にある。加え て、「市場の失敗」を補正する農業・食料政策の 形成及び実施においては、今後、政府のほかに民 間主体の役割も重要性を増すであろう。このよう な状況の下で、食料の生産者である農業者に限ら ず、企業・NGOの構成員を含む消費者の農業・ 食料政策に対する関心と態度が向上することは有 意義である。

教育内容としての農業の外部効果は、山下 
（2004）が提示した環境教育としての食文化教育 の 4 つの内容的構成要件をいずれも十分に満たす わけではない。しかし、各要件を充足させる要素 を持つ。さらに、指導者は「かかわりの全体性の 回復」、並びに世界や各国・地域の環境保全や持 続可能な社会の構築において、重要度の高い教育 内容をその効果から選択し、組織することができ る。農業の外部効果の個々の影響に対する社会的 評価は将来的に変化しうるが、そうした変化に指 導者は適切に対応していくことが可能である。農 業の外部効果は環境教育としての食文化教育の要 件を満たすにあたり、不可欠にして鍵となる教育 内容であるといえよう。

今後の課題のひとつは、環境教育としての食文 化教育の系統化・体系化を図るため、他の鍵とな る教育内容を検討すること、そしてそれら教育内 容相互の関連を明確化することである。

$2 つ$ 目の課題は、農業の外部効果の教育方法を 環境教育の立場から検討することである。例え ば、学習者の発達段階、農学及び教育学の成果、 教材の開発状況などを踏まえて、現場の指導者に 教育方法上の指針を示唆することが求められる。

\section{謝 辞}

本稿を作成するにあたり、近畿大学の池上甲一 先生、京都精華大学の井上有一先生、岐阜大学の 今村光章先生、京都大学大学院のSteven R. McGreevy氏からご教示を頂いた。記して、謝意 を表します。

\section{注}

1 ) 国際文書、及び国内の行政文書における環境 教育の理念を整理した文献として、市川智史 (1997)、川嶋宗継ほか（2002）がある。

2 ）この点については、研究動向をまとめている 鈴木・松葉口 (2005)、野村卓（2009）を参照 されたい。

3 ) 方法的要件を考察した論文に岩本廣美 (2001) がある。同論文では幼稚園や小学校における食 文化教育の実践事例を数多く検討し、環境教育 において食文化に関わる体験活動をどのように
構成すべきか、その原理を検討している。

4 ）例えば、家庭や外食店の食卓に並ぶ肉片から、 材料である動物の誕生・飼育・流通過程の自然 と人間とのかかわり、つまり精神的・社会的・ 経済的なかかわりの総体を認識することは容易 ではない社会状況が挙げられる。

5 ）環境教育としての食文化教育の内容的構成要 件に関し、山下 (2004) が提示した視点は現時 点において幅広く、妥当である。とはいえ、「食」 に関する自然と人間とのかかわりの関係性の様 態は、動的である。ゆえに、その変化に対応し た適切な要件については、今後検討の余地が残 されている。

6 ）凸性の条件は、完全競争市場における均衡 （equilibrium）を保証する価格体系が存在する 条件で、無差別曲線 (indifference curve) や 等量曲線（isoquant）が原点に対し凸であるこ とを求めるものである。

7 ）井上有一（2005）は、エコロジー思想の主張 は「環境持続性」「社会的公正」「存在の豊かさ」 の3つの価值から捉えることができるとし、「持 続可能性に向けての教育」はこれら価值と高い 整合性を保ちつつ、その内実を具体化していく べきであると論じている。ここでの「社会的公 正」には、資源分配上の実質的な公平さを実現 することが含まれている。

8 ) 内部経済効果とは、ある経済主体の行動が市 場の均衡条件の経路を通じて、他の経済主体の 制約条件や目的関数に影響を与えるもののう ち、享受者によって対価が支払われる効果の意 味で使用されている。同効果を発揮する機能の 内訳は「農林産物生産 (安全農産物安定供給) 」、 「所得 - 資産形成（農家所得形成、地域雇用派 生、資産維持)」機能である。

9 )この用法と同じく、従来農業経済学において 多面的機能 (multifunctionality) は、農業生産 活動に伴って生じる正の外部効果を称して用い られてきた傾向がある（日本学術会議 2001 24）。だが、この用語は各国が貿易交渉で異な る意味で政治的に使用していること（作山 2006 ; 今泉 2010)、OECD（2001）による独自 
の定義があることなどから多義的である。

10）農業の外部経済を対象とする貨幣換算評価 手法の種類と適用範囲、並びに諸手法の利点と 弱点については、浅野（1998）に論点が整理さ れている。

11）本稿における地域の意味は「個人・家族と いう社会の最小単位と国家との間に形成されて いるメゾ領域」（池上 2009）である。

12）そのルートの例には審議会・検討会におけ る委員、政策形成過程において開催される市民 参加型のシンポジウム・ワークショップ・円卓 会議、政策案の公開と意見提出からなるパブ リックコメント制度、個別事案ごとに実施され る住民投票が挙げられている。

13）国内農業の外部経済に対する多面的な意味 づけは、例えば日本農政の認識を表す『農業白 書』において1980年代から（秋津 1996 ; 佐藤・ 横川 2000)、小学校社会科教科書では2001年 検定済教科書から顕著に見受けられる（杉本 2008)。

14）大賀圭治（2004 173）を参考にしている。

15）消費者教育と環境教育は連接するゆえに、 今村光章（1995）のように、両者を統合する原 理を研究することが行なわれている。

16）消費者の食品選択の意思決定に活用される 情報として、細野ひろみ（2009）は「外部情報」 （表示や店内放送のように商品選択の場ではじ めて見たり聞いたりする情報）と、「内部情報」 （過去の経験や知識などのように消費者がすで に持っている情報）を示している。

\section{引用文献}

阿部道彦・佐島群巳，2004, 「食農教育の系譜と 展望」,『環境教育』, 14(2)：42-55.

秋津元輝，1996，「基本法下における農政の農村 認識 一白書記述の分析を通して一」, 『村落社 会研究』, 2(2)：19-30.

浅野耕太, 1998, 『農林業と環境評価 一外部経済 効果の理論と計測手法 - 』, 多賀出版, 東京, $181 \mathrm{pp}$.

浅野耕太, 2008, 「環境問題の経済学的基礎」, 諸
富徹ほか著『環境経済学講義』，有斐閣，東京， 23-39.

細田衛士, 2007, 「環境問題と環境経済学」, 細田・ 横山著『環境経済学』, 有斐閣, 東京, 1-25. 細野ひろみ, 2009, 「消費者の食品選択行動 - 消

費者は生産物やフードシステムをどう認識し、 何を求めているかー」、農業と経済』, 75(11)： 33-44.

市川智史，1997，「環境教育に関連するステート メント等」, 野上編『総合的学習への提言 第 7 巻「フィールド学習」理論と方法』, 明治図書, 東京, 169-188.

池上甲一，2009，「地域の豊かさと地域キャピタ ルを問うことの意味」, 『農林業問題研究』, 44 (4) : 3-9.

今泉友子, 2010 , 「多面的機能論の到達点と WTO体制下の農政改革」, 『農業法研究』, $45: 128-143$.

今村光章，1995，「消費者教育と環境教育の統合 を求めて」, 『関西教育学会紀要』, 19:41-45. 井上有一，2005，「エコロジー思想と持続可能性 に向けての教育 - 環境持続性・社会的公正・ 存在の豊かさを基軸としてー」, 今村編『持続 可能性に向けての環境教育』, 昭和堂, 京都, 87-114.

岩本廣美，2001，「環境教育における体験活動の 構成原理 - 食文化に関わる内容を中心に一」, 『奈良教育大学附属自然環境教育センター紀 要』, $4: 1-14$.

嘉田良平, 1999, 「農業環境研究における今後の 課題と展望」, 嘉田・西尾監修『農業と環境問 題』, 農林統計協会, 東京, 190-194.

川嶋宗継ほか，2002，『環境教育への招待』，ミネ ルヴァ書房, 京都, $298 \mathrm{pp}$.

北村和夫, 2000 , 『環境教育と学校の变革 -ひと りの教師として何ができるかー』, 農山漁村文 化協会, 東京, 366pp.

鬼頭秀一，1996，『自然保護を問いなおす－環境 倫理とネットワークー』, 筑摩書房, 東京, 254pp.

国立教育政策研究所，2007，『環境教育指導資料 
小学校編』, 東洋館出版社, 東京, $108 \mathrm{pp}$.

倉阪秀史, 2004, 『環境政策論 一環境政策の歴史 及び原則と手法-』, 信山社, 東京, $180 \mathrm{pp}$.

松葉口玲子, 2000, 『持続可能な社会のための消

費者教育 一環境・消費・ジェンダーー』, 近代

文芸社, 東京, 313pp.

中島紀一, 2010, 「生物多様性の保全と農業・農

村技術政策の転換」,『農業と経済』, 76(10)：

5-13.

日本学術会議, 2001 , 『地球環境・人間生活にか かわる農業及び森林の多面的な機能の評価につ いて (答申)』, http://www.scj.go.jp/ja/info/ kohyo/pdf/shimon-18-1.pdf（2011年2月 21 日 アクセス), 111pp.

野村卓，2009，「食と農をめぐる環境教育：『食・

農 (生産・消費)』一体化の流れと教育実践の

課題」,『環境教育』, 19(1)：113-124.

農林水産省, 2010a, 『食料・農業 - 農村白書 平

成 22 年版』, 佐伯印刷, 東京, $344 \mathrm{pp}$.

農林水産省, 2010b, 『食料・農業 - 農村白書参 考統計表 平成 22 年版』, 佐伯印刷, 東京, 193pp.

OECD, 2001, "Multifunctionality: Towards an Analytical Framework”, Paris, 159pp.

緒方隆, 2006,「外部効果」, 緒方ほか編『公共経 済学』, 勁草書房, 東京, 53-80.

小野瀬剛志, 2010,「社会システムとしての食糧 問題と食環境概念の再検討 - 食教育の概念的 整理にむけて-」, 『環境教育』, 20(1)：68-79.

大賀圭治, 2004 , 『食料と環境』(環境学入門 7 ), 岩波書店, 東京, 200pp.

ピグウ，1954，『ピグウ厚生経済学 第4 版』（気 賀健三ほか訳), 第 II 巻, 東洋経済新報社, 東京, 422pp.

作山巧，2006，『農業の多面的機能を巡る国際交

渉』, 筑波書房, 東京, $163 \mathrm{pp}$.

佐藤剛史・横川洋, 2000, 「わが国における農業

の多面的機能論の遷移と景観概念の解明 - 景 観視点からの農業の多面的機能構成要素の分類 - 」, 『九州大学大学院農学研究院学芸雑誌』, 55(1) : 93-109.
佐藤和夫, 2000 , 「農業・農村における外部効果 の経済的評価と費用負担に関する環境経済学的 研究 - 北海道農業の公益的機能と外部不経済 - 」, 『北海道大学農学部邦文紀要』, 23(2) : 61-118.

食料・農業・農村基本政策研究会, 2000, 『逐条

解説 食料 - 農業 - 農村基本法解説』, 大成出版

社, 東京, $365 \mathrm{pp}$.

消費者教育支援センター, 2006, 『消費者教育体

系化のための調査研究報告書』, http://www. consumer-education.jp/nice/（2011年4月 25 日アクセス), $37 \mathrm{pp}$.

祖田修, 2000, 『農学原論』, 岩波書店, 東京, 312 pp.

杉本史生, 2008, 「小学校社会科教科書第 5 学年 における農業の外部効果記述の変遷 - 文部省 と民間 2 社の著作・編集教科書を事例に - 」, 『日本農業教育学会誌』, 39(2)：73-93.

鈴木善次, 1993, 「環境教育として『食と農』を どう教えるか」、『自然と人間を結ぶ』，7(4)： 2-9.

鈴木善次, 2002,「食・農・土・健康」, 川嶋ほか 編『環境教育への招待』, ミネルヴァ書房, 京都, 93-99.

鈴木善次, 2007, 「持続可能な社会を築く食環境 の学習 - 現代の食環境教育論」, 鈴木監修『食 農で教育再生』, 農山漁村文化協会, 東京, 188-204.

鈴木善次・松葉口玲子, 2005,「日本における『食 環境』をめぐる環境教育に関する研究の動向」, 『環境教育』, 15(1)：62-75.

常木淳, 2002, 『公共経済学 第2版』, 新世社, 東 京, 233pp.

植田和弘, 1996, 『環境経済学』, 岩波書店, 東京, 220pp.

UNESCO-UNEP, 1976 , “CONNECT EN VIRONMENTAL EDUCATION NEWSLETTER”, I (1) : 1-9.

山下宏文，2004，「環境教育における『食』の扱 い - 食文化教育の構成要件 $-」$, 『環境教育』, 14(2) : 142-150. 